\title{
AN IMPACT AND COST-BENEFIT ANALYSIS OF AN EMPLOYEE ASSISTANCE PROGRAMME AT A SOUTH AFRICAN BANK
}

\section{Cammy Orren, LourieTerblanche}

\section{INTRODUCTION}

According to Follis (2001:37), "Without people (or human resources) organisations would not be able to function and deliver their products or services to their customers". In addition to the important role that people play, Employee Assistance Programmes (EAPs) are designed to enable management to build the productivity capacity of each individual in the organisation (Malatji, 2001:34). It is therefore essential that the human resource sector of organisations is managed and developed in order to optimise the individual and group capacity of human resources to reach these organisational objectives and personal goals.

An essential part of human resource management is managing the performance and motivation of employees. This can be achieved through ongoing and individual direct motivation of all employees through positive reinforcement, coaching and counselling. In the researchers' view, an EAP is one of the tools that line managers and human resource staff can utilise in enhancing motivation. Gòmez-Mejia, Balkin and Cardy (2001:451) state that "Employee assistance programs are designed to help employees whose emotional or psychological troubles are affecting their work performance". Merrick (2002:43) summarises this view succinctly: "In theory, EAPs should improve workplace efficiency and reduce absenteeism. The idea is that employees who are under less stress will focus more on work and take less time off."

Proof of the impact of EAPs in the workplace will empower EAP practitioners to market their programmes more effectively. Should such proof not be available, the results could be detrimental, not only on the growth of EAPs as a discipline, but also on troubled employees. Employees will be denied the opportunity and the right to access the help and assistance they may need.

The aim of the study on which this article is based was to evaluate the impact of EAP interventions on several work performance indicators of formally referred employees (referrals by supervisors) from a large South African employer within the banking industry and to determine the cost benefit of these interventions. Information for the research was obtained from three existing resources: organisational records, records of the Careways Group (EAP service provider) and a survey amongst managers who had formally referred employees to the EAP.

The findings of the study on which this article is reporting proved the impact of EAP interventions on the work performance of formally referred EAP clients, and indicated the cost benefit of such interventions for the organisation based on reduced absenteeism and a reduced number of disciplinary actions (Orren, 2004).

\section{RESEARCH DESIGN}

\section{Research hypothesis}

The primary goal of the study on which this article is based was to evaluate the impact of EAP interventions on several work performance indicators of formally referred employees at a South African national organisation within the banking sector and to determine the cost benefit of such interventions, with the aim of testing the following hypothesis: If troubled employees 
participate in the EAP, productivity indicators would be positively impacted upon, resulting in cost benefits for the organisation.

Durkin (1985:247) suggests that it is astute to separate impact assessment from cost-benefit analysis because of the possibility that "a program that has a positive impact is not necessarily producing a positive cost-benefit result". For this reason, the researchers separated the study into two parts. The first part consists of data obtained through a management survey on the impact of the EAP, whilst the second part consists of data obtained from the management information system on absenteeism.

\section{Participants}

The research population was obtained by means of a purposive sample of all EAP formally referred employees at the selected banking institution for the period January to December 2003.

The results indicated that 38 formal referrals were made by supervisors and managers during this period. However, nine of the referred employees never contacted the EAP after being referred by their managers. They therefore were excluded from the study. The research population was referred from six of the eleven divisions of the organisation, thereby making it relatively representative of the total organisation.

The sample represented referrals from six provinces of South Africa, thereby achieving the objective of a national study. The researchers are, however, of the opinion that the results could not be generalised to employees in the banking sector across South Africa, utilising EAPs because of the limited number of respondents involved in the study.

The researchers encountered significant challenges in making initial contact with most of the referring managers as respondents in order to obtain the required information. Furthermore, due to restructuring within the organisation, many of the referring managers had been transferred, had left the employ of the organisation, or were disgruntled by the restructuring and not prepared to participate in the survey. Obtaining hard data on employee productivity is one of the key challenges that Collins (1998:16) claims prevent EAP evaluation from being reported. All of these factors contributed to the final research population being reduced to 15 respondents, as seven of the managers had left the employ of the organisation and seven managers were either not prepared to participate, did not respond to messages left by the researchers, or did not return completed questionnaires after agreeing to participate.

The resulting response rate was therefore $52 \%$ of the research population, originating from five of the divisions of the company. Eighty-seven percent of them were from the two largest divisions of the organisation, representing three of South Africa's provinces. The majority of respondents were based in Gauteng, where there is the highest concentration of staff. Although the response rate was not as high as expected, the spread of the research population is relatively representative of the organisation nationally.

\section{Methods of data gathering}

The empirical part of the research reflected on two parts of the evaluation process. The first part - reflecting on the impact of the EAP - consisted of data on productivity changes of referred employees pre- and post-EAP intervention. This set of data was obtained according to the quantitative survey design with structured questionnaires (as the data collection instrument) completed by the referring supervisors and managers (respondents).

The second part - reflecting on the cost benefit of the EAP - involved a collection of statistical data on employee absenteeism records (pre- and post-EAP intervention) which was obtained 
from the organisation's management information system (MIS). Data analysed on the other component included in the cost-benefit component of the study - disciplinary records (pre- and post-EAP intervention) - were obtained from the completed questionnaires received back from referring supervisors and managers (respondents) and not from the MIS.

TABLE 1

CHANGES IN WORK PERFORMANCE FACTORS AFTER EAP INTERVENTION: VIEWS FROM REFERRING SUPERVISORS AND MANAGERS

\begin{tabular}{|c|c|c|c|c|c|c|c|c|c|c|}
\hline \multicolumn{9}{|c|}{ CHANGES IN WORK PERFORMANCE FACTORS } & \\
\hline \multirow{3}{*}{\begin{tabular}{|c|} 
WORK \\
PERFORMANCE \\
FACTOR \\
\end{tabular}} & \multicolumn{2}{|r|}{1} & \multicolumn{2}{|r|}{2} & \multicolumn{2}{|c|}{3} & \multicolumn{2}{|r|}{4} & & \\
\hline & \multicolumn{2}{|c|}{ IMPROVED } & \multicolumn{2}{|c|}{$\begin{array}{l}\text { SLIGHTLY } \\
\text { IMPROVED }\end{array}$} & \multicolumn{2}{|c|}{$\begin{array}{c}\text { REMAINED THE } \\
\text { SAME }\end{array}$} & \multicolumn{2}{|c|}{$\begin{array}{l}\text { GOT } \\
\text { WORSE }\end{array}$} & \multicolumn{2}{|l|}{$\begin{array}{c}\text { TOTAL } \\
\mathrm{n}=15\end{array}$} \\
\hline & No & $\%$ & No & $\%$ & No & $\%$ & No & $\%$ & \begin{tabular}{|l}
$\mathrm{N}=$ number of \\
respondents to \\
specific question
\end{tabular} & f \\
\hline Negative attitude & 3 & $37.5 \%$ & 2 & $25 \%$ & 2 & $25 \%$ & 1 & $12.5 \%$ & 8 & 100 \\
\hline Low morale & 4 & $57 \%$ & 3 & $43 \%$ & & & & & 7 & 100 \\
\hline $\begin{array}{l}\text { Low } \\
\text { concentration }\end{array}$ & 2 & $29 \%$ & 4 & $57 \%$ & & & 1 & $14 \%$ & 7 & 100 \\
\hline Absenteeism & 3 & $43 \%$ & & & 3 & $43 \%$ & 1 & $14 \%$ & 7 & 100 \\
\hline $\begin{array}{l}\text { Extended meal } \\
\text { breaks }\end{array}$ & & & & & & & & & & 100 \\
\hline $\begin{array}{l}\text { Arriving late for } \\
\text { work }\end{array}$ & 2 & $50 \%$ & & & 2 & $50 \%$ & & & 4 & 100 \\
\hline $\begin{array}{l}\text { Leaving work } \\
\text { early }\end{array}$ & & & & & 1 & $100 \%$ & & & 1 & 100 \\
\hline $\begin{array}{l}\text { Not meeting } \\
\text { deadlines }\end{array}$ & 1 & $100 \%$ & & & & & & & 1 & 100 \\
\hline $\begin{array}{l}\text { Not achieving key } \\
\text { performance } \\
\text { targets }\end{array}$ & 1 & $33.33 \%$ & 1 & $33.33 \%$ & & & 1 & $33.33 \%$ & 3 & 100 \\
\hline Medical problems & 2 & $25 \%$ & 2 & $25 \%$ & 2 & $25 \%$ & 2 & $25 \%$ & 8 & 100 \\
\hline Legal problems & 2 & $100 \%$ & & & & & & & 2 & 100 \\
\hline $\begin{array}{l}\text { Financial } \\
\text { problems }\end{array}$ & 2 & $33 \%$ & 1 & $17 \%$ & 3 & $50 \%$ & & & 6 & 100 \\
\hline $\begin{array}{l}\text { Poor relationship } \\
\text { with co-workers }\end{array}$ & 1 & $20 \%$ & 1 & $20 \%$ & 2 & $40 \%$ & 1 & $20 \%$ & 5 & 100 \\
\hline $\begin{array}{l}\text { Poor relationship } \\
\text { with manager }\end{array}$ & 2 & $67 \%$ & & & & & 1 & $33 \%$ & 3 & 100 \\
\hline $\begin{array}{l}\text { Inferior client } \\
\text { service }\end{array}$ & 2 & $50 \%$ & 1 & $25 \%$ & 1 & $25 \%$ & & & 4 & 100 \\
\hline \begin{tabular}{|l|} 
Disciplinary \\
action taken \\
against employee
\end{tabular} & 2 & $100 \%$ & & & & & & & 2 & 100 \\
\hline $\begin{array}{l}\text { Employee using } \\
\text { grievance } \\
\text { procedure }\end{array}$ & 1 & $100 \%$ & & & & & & & 1 & 100 \\
\hline
\end{tabular}

* Although $\mathrm{n}=15$, the number of responses exceeded 15 as respondents were not limited to one factor, but were expected to comment on different work performance factors where appropriate. 


\section{PART A - IMPACT OF THE EMPLOYEE ASSISTANCE PROGRAMME}

Data in this part are results from the survey amongst referring supervisors and managers.

\section{Results - Manager's Survey}

The study on the impact of the EAP achieved significantly positive results. Table 1 summarises the total number of changes in work performance factors after EAP intervention in a numerical and percentage format, as rated by the referring supervisors and managers.

This part of the study indicated that a variety of work behaviours is impacted on when an employee experiences a work-related or psycho-social problem. The only two factors in the questionnaire that did not show any improvement whatsoever since the introduction of the EAP, were Leaving Work Early and Extended Meal Breaks. The latter factor was not rated at all by any of the respondents.

For the performance indicators that did not show improvement after EAP intervention, many of the responses either indicated that the referred employee was not willing to participate fully in the counselling process, or that the reason for non-improvement was not work-related, for example, transport and financial problems.

Table 2 summarises the results received from the Manager's Survey from 15 respondents, indicating the percentage improvement in various work performance and related factors resulting from EAP intervention.

TABLE 2

SUMMARY OF MANAGER SURVEY RESULTS

\begin{tabular}{|l|c|}
\hline \multicolumn{1}{|c|}{ Description } & $\begin{array}{c}\text { \% improvement } \\
\text { n = 15 }\end{array}$ \\
\hline Negative attitude & 63 \\
\hline Low morale & 100 \\
\hline Low concentration & 86 \\
\hline Absenteeism & 43 \\
\hline Arrive late at work & 50 \\
\hline Missed deadlines & 100 \\
\hline Not achieving key performance targets & 66 \\
\hline Medical problems & 50 \\
\hline Legal problems & 100 \\
\hline Financial problems & 50 \\
\hline Poor relationship with co-workers & 40 \\
\hline Poor relationship with managers & 67 \\
\hline Inferior client service & 75 \\
\hline Disciplinary action against employee & 100 \\
\hline Employee using grievance procedure & 100 \\
\hline
\end{tabular}

Note: The contents of Table 2 provide the same data as reflected in Table 1, but in a summarised format (example Approved combined with Slightly approved).

The results of the Manager Survey indicate that the impact of the EAP on work performance factors at the research organisation is positive for the majority of formally referred employees. 
These results are in accordance with other EAP impact studies (Meyer, 1994:110; Oher, 1999:117-137).

\section{Discussion of data - Manager's Survey}

Some of the comments received from respondents indicated that managers within the organisation do not make use of EAP formal referrals for the management of poor work performance. This observation was confirmed during the analysis of statistical data, when the reason for referral indicated by the referring supervisors and managers showed that only $36 \%$ of referrals were made as a result of work-related issues.

The results of the survey also showed that, in some cases, managers do not seem to monitor employee attendance during the working day (e.g. extended meal breaks or leaving the workplace early), as those questions were not answered. The work performance factors included and tested through the survey amongst referring managers will be discussed according to the different categories:

\section{Factors focused on attitude and morale}

A strong improvement was indicated in Negative Attitude and Low Morale, which also correlates with the assumption that the mere introduction of an EAP itself does have motivational value - most likely resulting from the fact the employees do experience that the company cares about them. Hyatt (2007:22) states in this regard that EAP practitioners can demonstrate leadership as behavioural risk managers when an employee is unable to function because of psychological distress.

\section{Factors focused on absenteeism}

Storey (2000:4) expresses the following view on the impact of absenteeism in the workplace: "It is a well-known fact that absenteeism in the workplace results in a loss of production, increased labour costs for replacement staff (or added overtime for other staff), increased administrative burdens, lowered morale and additional stress among remaining employees". Hamilton-Atwell, Engelbrecht and Pienaar (2002:2) also agree about the impact of absenteeism in the workplace and claim that absenteeism is one of the most convoluted of the employee problems. They assert: "Employee lateness and absence are two of the most costly and disruptive employee problems faced by business ... [they have] a significant impact on the productivity of an organisation". Hamilton-Atwell et al. (2002:1) further suggest that South African companies have a complacent attitude towards the significance and cost levels of absenteeism as a result of years of isolation and lack of global competition.

According to Hamilton-Atwell et al. (2002:3), the impact of absenteeism can be observed throughout various levels in organisations, including organisational productivity, the employees themselves and the unions. For the purposes of this study, the impact of absenteeism on organisational productivity will be the focus. It was found that the consequences of employee absenteeism may include:

- lower productivity;

- lower morale;

- increased costs due to overtime and replacement employees;

- late deliveries;

- dissatisfied customers;

- reduced competitiveness; 
- eroded discipline;

- increased friction between management and employees leading to a deterioration of workplace relations.

Authors agree (Cascio, 1982:46; Cilliers, 1977:5; De Villiers, 1992:5; Hamilton-Atwell et al., 2002:5) that absenteeism occurs in various forms. The most prevalent types of absenteeism are:

- authorised absence, including annual leave, sick leave and contingency leave; and

- unauthorised absence, including involuntary absence (reasons beyond an employee's control), voluntary absence (reasons within an employee's control), late arrival, abandonment, and strikes and industrial action.

Despite the fact that absenteeism and its different forms are often identified as the major problem amongst employees that impacts on their production, the authors believe that absenteeism is the indicator of an underlying problem and not the problem itself.

Managers confirmed a strong improvement (43\% and 50\% respectively) in rectifying the phenomenon of absenteeism and arriving late for work. This could be a direct result of the EAP addressing those factors leading to or resulting in absenteeism of whatever form. Changes or improvements in a pattern of absenteeism can also be identified more accurately by supervisors and managers compared to some of those implied factors, which may not be as measurable as absenteeism, i.e. lowered productivity or lowered motivation.

\section{Factors focused on low output}

EAPs are often associated with, and also marketed as a tool for, the improvement of productivity of employees. Jones (1985:7) puts forward two reasons in this regard. Firstly, and closely linked to the cost-effectiveness argument, is the notion that an organisation may implement an EAP because of poor production results. Secondly, Jones refers to the possibility that the loss of a valuable employee as a result of suicide or dismissal as a result of alcoholism may induce an organisation to implement an EAP.

Measurement of productivity, though, is difficult as the concept of productivity is based on a variety of variables that need to be taken into consideration. Mere output or lack thereof, however, is an accepted way of 'measuring' the productivity in the workplace. Respondents in this study (Table 2) confirmed an improvement (100\% in meeting deadlines, $86 \%$ in concentration level, $75 \%$ in improved client service and 66\% in achieving key performance targets) in those factors determining the output of the employee.

\section{Factors focused on relationships}

Distorted relationships in the workplace, whether they be supervisory relationships, relationships with peers or subordinates, are recognised indicators of an underlying problem amongst employees in the workplace. Sonnenstuhl and Trice (1986:6) maintain that some organisations implement EAPs as a method to evade conflict in the workplace. Respondents in this study confirmed an improvement varying between $40 \%$ (improved relationships with coworkers) and 67\% (improved relationship with managers) (Table 2).

\section{Factors focused on disciplinary and related actions}

Troubled employees - wrongly managed - very often land up facing disciplinary actions and/or grievance procedures because they are experiencing personal problems. EAPs are adopted by organisations for various reasons, according to Sonnenstuhl and Trice (1986:6). They firstly claim that some organisations have ideological reasons based on social responsibility, and that 
it is "good business" to assist employees in addressing their personal problems. Secondly, they suggest the cost effectiveness of EAPs as a reason. Other authors (Challenger, 1988:7; Jones, 1985:7) also support the cost effectiveness and social responsibility reasons. However, Challenger (1988:7) suggests three other factors that can form part of the rationale for implementing EAPs. Firstly, this author suggests that EAPs may be implemented to retain valuable employees, as there is a rehabilitation rate of up to $80 \%$. Secondly, Challenger refers to the enhancement of management/union relationships as a rationale. Lastly, he suggests that companies adopt EAPs because of the "no-lose situation" that they create by receiving a high return on investment as a result of offering assistance to staff members and their families. An improvement in the number of disciplinary hearings - measurement based on a decline in the number - was confirmed by $100 \%$ of the respondents and should certainly be seen as a major consequence of the EAP on the workforce of the specific organisation. Information on this component is also covered in the cost-benefit section of this study.

\section{Factors focused on medical, legal and financial problems}

Personal problems amongst employees are often associated with medical, legal and financial problems of some nature. Wilburn (2007:12) refers to an increase in the number of cases being referred to the EAP as a result of financial problems.

In the current study an improvement with regard to medical, financial and legal problems was confirmed by $50 \%, 50 \%$ and $100 \%$ of respondents, respectively (Table 2 ).

\section{Comments on Managers' Survey on the impact of the Employee Assistance Programme}

Based on the pilot testing, the actual application of the questionnaire used in the current study as the measuring instrument and the responses received, the researchers believe that the questionnaire can be utilised by all EAP practitioners, EAP professionals and organisations in South Africa as a tool to measure the impact of EAPs. Although this study focused primarily on formal referrals, it would be possible to make slight adjustments to the questionnaire to make it applicable to both informal and self-referrals also.

\section{PART B - COST-BENEFIT STUDY}

\section{Results - data from the Management Information System}

Although managers at the banking institution being researched had all been trained to make EAP formal referrals on the basis of poor work performance of employees, it seems that many of the referrals (64\%) were not the result of work-related issues. This is similar to the findings at Chevron Corporation in the USA, where an EAP cost-benefit analysis revealed that supervisors were frequently reluctant to make formal referrals, as such formal referrals are confrontational by nature and have disciplinary implications (Collins, 1998:19).

However, the results also seem to indicate that managers at the banking institution have an interest in the wellbeing of their subordinates, and use the EAP as a resource to address personal problems impacting on work performance.

\section{Absenteeism}

The absenteeism records were divided into two primary categories, namely planned absenteeism (annual leave) and unplanned absenteeism. The focus of the research was on the unplanned absenteeism, including sick leave, family leave, unpaid leave and incidental annual leave (three days and less). Table 3 summarises the results of the absenteeism analysis: 
TABLE 3

SUMMARY OF UNPLANNED ABSENTEEISM RECORDS

\begin{tabular}{|l|c|c|c|c|}
\hline \multicolumn{1}{|c|}{ Category } & \multicolumn{2}{c|}{ Sick, family and unpaid leave } & \multicolumn{2}{c|}{ Incidental annual leave } \\
\hline Period & Before EAP & After EAP & Before EAP & After EAP \\
\hline Number of days & 54 & 43 & 11 & 9 \\
\hline Average for 4 months & 7.7 & 6.1 & 1.6 & 1.3 \\
\hline Average for 1 month & 1.9 & 1.5 & 0.4 & 0.3 \\
\hline $\begin{array}{l}\text { Organisational average for 4 } \\
\text { months }\end{array}$ & \multicolumn{2}{|c|}{0.3} & \multicolumn{2}{c|}{ Unknown } \\
\hline \% improvement & \multicolumn{2}{|c|}{$\mathbf{2 0}$} & \multicolumn{2}{c|}{$\mathbf{1 8}$} \\
\hline
\end{tabular}

The results of the analysis of unplanned absenteeism pre- and post-EAP intervention (sick, family, unpaid leave and incidental annual leave) show an improvement of $20 \%$ and $18 \%$ respectively.

For sick, family and unpaid leave the number of absentee days declined from 54 days to 43 days, and for incidental annual leave, the number of absentee days declined from 11 days to nine days. Although these results are not significant, they show a positive impact on unplanned absenteeism after EAP intervention of formally referred EAP clients. These results are in accordance with a number of studies carried out with regard to the City of Los Angeles Department of Water and Power (Hocket, 1987), McDonnell Douglas Corporation (Hocket, 1987), a study conducted at an Anglo American Gold Mine (Liebenberg, 1990), Detroit Edison (Highley \& Cooper, 1994), Illinois Bell (Shear, 1995), Utah Power and Light (Shear, 1995) and Chevron Corporation (Collins, 1998).

\section{Disciplinary action}

Based on feedback received from the results of the EAP Managers' Survey, the results showed that incidents of disciplinary action against the 15 referred employees improved by $71 \%$ after EAP intervention, indicative of an impact on this indicator. Prior to EAP intervention, there were 24 incidents of disciplinary action, and this reduced to seven incidents post-EAP intervention. However, because of the absence of data regarding organisational averages, it was not possible to gauge whether the EAP intervention was solely responsible for the improvement.

\section{Discussion of data from the Management Information System}

The cost-benefit analysis was conducted with the same sample group of EAP clients as for the EAP impact study. In the cost-benefit analysis, the researcher compared the estimated monetary costs with the benefits (savings) of the EAP; after this the economic efficiency of the EAP was expressed in terms of savings per rand invested.

\section{Estimation of costs}

The average cost per EAP client per annum was calculated as follows (French \& Zarkin, 1995:468): 


\section{TABLE 4}

AVERAGE COSTS PER EMPLOYEE

\begin{tabular}{|l|l|l|}
\hline \multicolumn{1}{|c|}{ Item } & \multicolumn{1}{|c|}{ Description } & \multicolumn{1}{c|}{ Amount } \\
\hline Total cost of EAP & Total contract fee for 2003 & R2 409 951.50 \\
\hline Number of eligible employees & $\begin{array}{l}\text { Total number of employees eligible } \\
\text { to use EAP in 2003 }\end{array}$ & 23400 \\
\hline Number of employees served & $\begin{array}{l}\text { Total number of employees who } \\
\text { actually used EAP services in 2003 }\end{array}$ & 1638 \\
\hline $\begin{array}{l}\text { Average cost per eligible } \\
\text { employee }\end{array}$ & $\begin{array}{l}\text { Total cost divided by number of } \\
\text { eligible employees }\end{array}$ & $\begin{array}{l}\text { R102.98 } \\
\text { (R8.58 per month) }\end{array}$ \\
\hline $\begin{array}{l}\text { Average cost per employee } \\
\text { served }\end{array}$ & $\begin{array}{l}\text { Total cost divided by the number of } \\
\text { employees served }\end{array}$ & $\begin{array}{l}\text { R1471.28 } \\
\text { (R122.61 per month) }\end{array}$ \\
\hline
\end{tabular}

The average cost per EAP client per annum was calculated according to a formula developed by French and Zarkin (1995:468).

\section{Estimation of benefits}

The benefits of the EAP were denoted by the estimated savings due to reduction in absenteeism and disciplinary action after EAP intervention.

\section{Benefit/cost ratio}

The benefit/cost ratio was calculated by dividing the total average savings per EAP client by the average cost per EAP client (Meyer, 1994:110). If the total savings are greater than the cost, the ratio will be a figure higher than 1 . If the figure is lower than 1, the costs of the EAP are higher than the savings. In essence, the ratio (if higher than 1) would represent an RX return for every R1 spent on the EAP during the period after EAP intervention.

\section{Results of cost-benefit analysis}

Table 5 summarises the results of the cost-benefit analysis.

\section{TABLE 5 \\ SUMMARY OF RESULTS OF COST-BENEFIT ANALYSIS}

\begin{tabular}{|l|c|c|c|}
\hline $\begin{array}{c}\text { Description of factor } \\
\text { being saved on }\end{array}$ & $\begin{array}{c}\text { Per employee per } \\
\text { month in study } \\
\text { sample } \\
\text { (n=15) }\end{array}$ & $\begin{array}{c}\text { All EAP clients per } \\
\text { month during 2003 } \\
\text { (n=1638) }\end{array}$ & $\begin{array}{c}\text { All potential EAP } \\
\text { clients per annum } \\
\text { during 2003 } \\
\text { (n=1638) }\end{array}$ \\
\hline SAVINGS & R217.37 & R356 052.06 & R4 272 624.72 \\
\hline Absenteeism & R44.22 & R72 432.36 & R869 188.32 \\
\hline Disciplinary action & R261.59 & R428 484.42 & R5 141 813.04 \\
\hline Total & R122.61 & R200 835.18 & R2 410 022.16 \\
\hline COSTS & 1 to 2 & 1 to 2 & 1 to 2 \\
\hline Total
\end{tabular}

The results of the cost-benefit analysis indicate that the savings of the EAP are greater than the costs, resulting in a $\mathrm{R} 2$ return for every $\mathrm{R} 1$ invested. 
Although this result is lower than those found in the researchers' literature study (Hocket, 1987; Maiden, 1988; Masi \& Goff, 1987; Merrick, 2002; Shear, 1995), it is important to note, firstly, that these savings (benefits) are only related to the conservative calculations based on reduced absenteeism and disciplinary action of EAP clients and do not include other work performance and intangible benefits. Secondly, the benefit-cost ratio is expressed as a minimum benefit per rand invested, as not all the benefits were included.

The results show that, if reduction in absenteeism and disciplinary action was deemed to be benefits of the EAP, the programme was cost effective for EAP clients during the study period.

Regarding changes in absenteeism as an EAP benefit, the results indicate a saving of R217.37 per month for EAP clients after EAP intervention, which calculates to a saving of R2 608.44 per EAP client per annum. If these results were to be extrapolated to an annual saving for the entire workforce entitled to EAP services during 2003, they would reflect a saving of R4 272624.72 (Table 5), which is significantly higher than the entire cost of the EAP contract for the year. Furthermore, the average reduction in absenteeism for EAP clients was 1.9 days, with a total reduction of $19 \%$, indicating a further benefit to the organisation. It is important to mention that some of the EAP clients showed reductions in absenteeism of between seven and 20 days after EAP intervention.

Regarding changes in disciplinary action as a benefit of the EAP, the results indicate a much lower saving of R44.22 per month for EAP clients after EAP intervention, amounting to a saving of R530.64 per EAP client per annum. If these results were to be extrapolated to an annual saving for the entire EAP client population for 2003, they would reflect a saving of R869 188.32 (Table 5). It is important to take into consideration that the researchers only used one hour per disciplinary action, and only took the relevant employee's salary into account. In practice, the time spent by managers on maintaining discipline and the cost of those managers' salaries could also be significant and be determined by the nature of the offence that led to the disciplinary action. These calculations are therefore conservative. The average reduction in incidences of disciplinary action for EAP clients was 1.1, with a total reduction of $71 \%$, indicating a further significant benefit to the organisation. In addition, some of the EAP clients had up to three fewer incidents of disciplinary actions after EAP intervention.

These results are within the expectations of the researchers, based on the literature study which was conducted as part of this research.

\section{Comments regarding data from Management Information System on the cost- benefit study}

Despite challenges experienced in obtaining the statistical data from the banking institution's Management Information System, the researchers believe that data collection from existing Management Information Systems can be utilised effectively in order to obtain data on the cost benefit of an EAP.

\section{COMMENTS ON METHODOLOGY}

One of the primary limitations of the research was the non-availability of comprehensive organisational employee data, and the study was therefore based on limited and sometimes incomplete data. Holosko (1988:65) states that "most organisations are 'information short' when it comes to having meaningful and retrievable information available for program evaluations". Highley and Cooper (1994:52) confirm this view and add questionnaire administration and selecting a comparison group as further possible challenges. For the same 
reason no comparisons to organisational trends and demographics could be made in the study. This is a significant methodological limitation of the research, as other factors or circumstances within the organisation cannot be excluded as reasons for the changes in performance indicators in EAP clients.

However, the researchers decided to conduct an overall outcome evaluation, where the overall change found in the group of employees after EAP intervention is measured, regardless of its true sources (Kim, 1988:179).

Regarding response rates, the researchers experienced low response rates from referring managers, despite repeated telephonic and email follow-ups. This limitation was one of the disadvantages stated by Delport $(2002: 172)$ for quantitative data collection by means of questionnaires.

The researchers discovered during the pilot study that the organisation's Management Information System (MIS) did not contain employee disciplinary records, as expected. The questionnaire for referring managers was therefore adapted to include a question on disciplinary action against referred employees for 12 months pre- and post-EAP intervention.

Regarding the cost-benefit analysis, Meyer (1994:147) argues that one of the problems inherent to cost-benefit analysis is that only benefits that have monetary value, or that could be translated into monetary terms, can be included in the analysis. In this study it was only possible to relate monetary benefits to two of a multitude of tangible benefits, so the results can only be seen as a measurement of those specific benefits. Furthermore, for the same reason many intangible benefits were also excluded from the cost-benefit analysis. It is therefore important to interpret the cost-benefit ratio as follows. The organisation's EAP saved R2 in absenteeism and disciplinary action for every R1 spent on the programme. As stated previously, the researchers ideally wanted to measure the cost benefit of improvement in employee work performance holistically; however, it was not possible to include all relevant aspects as part of the study.

Finally, another limitation related to the cost-benefit analysis was that regarding the period for which absenteeism statistics were used. Although the researchers originally planned to obtain data for twelve months pre- and post-EAP intervention, the period had to be reduced as the absenteeism data were available only for a four-month period for seven of the 15 EAP clients, because of limitations of the organisation's MIS. The impact and cost benefit related to absenteeism was therefore only measured in the short term. However, Yamatini (1988:132) argues that a period of between three and 12 months pre- and post-EAP interventions is acceptable.

The cost-benefit analysis for the banking institution could have been much more significant had comprehensive data been available for the full sample of 15 referred employees. Furthermore, had the sample been larger as a result of more formal referrals and increased willingness from managers to participate, the research could have indicated much more comprehensive results applicable to other business sectors and organisations in South Africa as well.

\section{CONCLUSIONS}

Based on the results obtained through this study and data on intangible benefits claimed by various authors (Csiernik, 1995:32; Durkin, 1985:254; Malatji, 2001:14) which also have a positive impact within the organisation, the actual monetary value resulting from successful programme intervention can be ascertained. 
As such, the researchers would like to support the view expressed by MacAlpine (2003:3), namely that "The cost-benefit potential and the cost-saving potential of any EAP will certainly be heightened the more the EAP can actually integrate within the organisation".

Proper integration and administration of the EAP will only be possible once evaluation is properly provided for as from the initial design phase throughout the day-to-day functioning of the EAP.

\section{Conclusions regarding the impact of EAPs on the workplace}

The researchers conclude that:

- participation in the EAP of employees from the banking institution resulted in improved productivity and improved relationships;

- participation in the EAP of employees from the banking institution resulted in a decline in financial, legal and medical problems; and

- participation in the EAP of employees from this banking institution resulted in a lower absenteeism figure and a lower number of disciplinary actions.

\section{Conclusions regarding the cost benefit of EAPs in the workplace}

The researchers conclude that:

- the results of the statistical data analysis show an average improvement of $19 \%$ in unplanned absenteeism and $71 \%$ in incidents of disciplinary action; and

- the lower absenteeism figure and lower number of disciplinary actions resulted in a savings of R2 for every R1 invested in the EAP.

\section{Conclusion regarding the hypothesis of the study}

The results of this study proved the validity of the hypothesis: If troubled employees participate in the EAP, productivity indicators would be positively impacted upon, resulting in cost benefits for the organisation.

\section{RECOMMENDATIONS}

The researchers wish to recommend that:

- the same research methodology as applied in this study should be considered by EAP professionals to enable organisations to determine the full impact of their programmes in terms of improving employee productivity and the return on their investment;

- EAP supervisory training should be made compulsory within organisations in order for line managers and the organisations to obtain the correct tools for managing poor work performance, and ultimately to achieve maximum benefit from their EAPs;

- line managers should be provided with a guideline during EAP supervisory training in order to monitor all work performance and behaviour of staff;

- future researchers should conduct a comprehensive situational analysis regarding the information that needs to be obtained from the research organisation(s), in order to prevent methodological and outcome constraints. For comparative purposes such information should include, amongst other things, baseline statistics on absenteeism, disciplinary action, employee turnover, medical claims and accidents, in addition to data on the demographics of the employee population; 
- a broader range of work performance indicators should be analysed and included as part of the cost-benefit analysis, in order to provide more comprehensive and more significant benefits (savings) through their EAPs;

- a combined method of obtaining the information should be used, for example, using both self-administered questionnaires and focus groups in order to accommodate the preferences of various respondents.

\section{CONCLUDING REMARKS}

The researchers are convinced that this study could make a contribution towards:

- addressing the limited availability of South African research in this specific field of EAPs;

- an improvement in the effectiveness of EAPs throughout South Africa, specifically as regards the importance of EAP evaluation, EAP supervisory training and EAP formal referrals for managing poor work performance;

- enhancing the importance of continuing and expanding EAP training for all business professionals at South African training institutions;

- ensuring that organisations with EAPs are obtaining the full benefit of their programmes in terms of improving employee productivity and achieving a return on their investment;

- an improvement in the availability of employee data within South African organisations, in order to provide management with valuable feedback regarding the effectiveness and financial benefit of their organisation's EAP;

- promoting a change in perception amongst line managers and organisational management so that an EAP is accepted as a valuable and essential performance management tool, rather than a 'nice to have' incidental instrument;

- enhancing the value and programme management of the EAP at the selected banking institution and other organisations within the same sector in South Africa;

- further expansion of EAPs within South African organisations that have been reluctant to implement these valuable programmes because of concerns about cost effectiveness and other misperceptions;

- ensuring that EAP practitioners have a user-friendly tool to conduct ongoing EAP evaluation for their client organisations, thereby advancing the value of the profession within South Africa; and finally;

- enhancing the service delivery of the EAP service provider company to its corporate clients by proving the effectiveness and cost benefit of their programmes and recommending enhancements when required.

\section{REFERENCES}

CASCIO, W.F. 1982. Costing human resources: the financial impact of behavior in organizations. Massachusetts: Kent Publishing Company.

CHALLENGER, B.R. 1988. The need for employee assistance programs. In: DICKMAN, E., CHALLENGER, B.R., EMENER, E.W. \& HUTCHISON, W.S. (jr) (eds) Employee assistance programs: a basic text. Illinois: Charles $\mathrm{C}$ Thomas Publisher.

CILLIERS, S.P. 1977. Absenteeism in Cape industries: a summary report. Stellenbosch: University of Stellenbosch. 
COLLINS, K.R. 1998. Cost/Benefit analysis shows EAP's value to employer. EAPA Exchange, November/December:16-20.

CSIERNIK, R. 1995. A review of research methods used to examine employee assistance program delivery options. Evaluation and Program Planning, 18(1):25-36.

DE VILLIERS, V. 1992. Afwesigheid van werk as verskynsel in die bedryf - 'n literatuurstudie. Johannesburg: Rand Afrikaans University. (Unpublished MA Dissertation)

DELPORT, C.S.L. 2002. Quantitative data collection methods. In: DE VOS, A.S., STRYDOM, H., FOUCHÉ, C.B. \& DELPORT, C.S.L. Research at grass roots: for the social sciences and human services professions $\left(2^{\text {nd }}\right.$ ed $)$. Pretoria: Van Schaik Publishers.

DURKIN, W.G. 1985. Evaluation of EAP programming. In: KLARREICH, S.H., FRANCEK, J.L. \& MOORE, C.E. (eds) The human resources management handbook: principles and practice of employee assistance programs. New York: Praeger Press.

FOLLIS, E. 2001. Organization development and human resources: Planning for the future. Organization Development Journal, 19(2):37-46.

FRENCH, M.T. \& ZARKIN, G.A. 1995. A methodology for evaluating the costs and benefits of employee assistance programs. Journal of Drug Issues, 25(2):451-471.

GÒMEZ-MEJIA, L.R., BALKIN, D.B. \& CARDY, R.L. 2001. Managing human resources $\left(3^{\text {rd }}\right.$ ed). New Jersey: Prentice-Hall.

HAMILTON-ATWELL, A. ENGELBRECHT, S. \& PIENAAR, T. 2002. Absenteeism in industry: a literature survey. South Africa: Business DNA.

HIGHLEY, J.C. \& COOPER, C.L. 1994. Evaluating EAPs. Personnel Review, 23(7):46-59.

HOCKET, R. 1987. EAP utilization and cost benefits. In: MAIDEN, R.P. (ed) EAPA facts. Chicago: University of Illinois.

HOLOSKO, M.J. 1988. Prerequisites for EAP evaluations: a case for more thoughtful evaluation planning. Employee Assistance Quarterly, 3:59-67.

HYATT, J. 2007. Addressing psychological fitness for duty, Journal of Employee Assistance, 37(2):22-24.

JONES, O.F. 1985. The rationale and critical issues of EAP development. In: KLARREICH, S.H., FRANCEK, J.L. \& MOORE, C.E. (eds) The human resources management handbook: principles and practice of employee assistance programs. New York: Praeger Press.

KIM, D.S. 1988. Assessing employment assistance programs: evaluation typology and models. Employee Assistance Quarterly, 3:169-188.

LIEBENBERG, C.J. 1990. Analysing the cost effectiveness of an employee assistance programme on an Anglo American Corporation gold mine. In: EAPs in practice in the South African context. A publication of the EAP Workgroup of Southern Transvaal and the Orange Free State:42-44.

MACALPINE, A. 2003. Today's EAPs offer services everyone can use. Benefits Canada, 27(10):1-3.

MAIDEN, R.P. 1988. Employee assistance program evaluation in a federal government agency. Employee Assistance Quarterly, 3(3/4):191-203. 
MALATJI, S.M. 2001. Get with the programme. People Dynamics, March:14-34.

MASI, D.A. \& GOFF, M.E. 1987. The evaluation of employee assistance programs. Public Personnel Management, 16(4).

MERRICK, N. 2002. Employee assistance programmes. Employee Benefits, February:41-48.

MEYER, A. 1994. Employee assistance programmes: a needs assessment and cost-benefit analysis. Cape Town: University of Cape Town. (Unpublished MA Dissertation)

OHER, J.M. 1999. Survey research to measure EAP customer satisfaction: a quality improvement tool. In: OHER, J.M. (ed) The employee assistance handbook. New York: John Wiley:117-138.

ORREN, C. 2004. An employee assistance programme impact and cost benefit analysis at a South African national organisation. Pretoria: University of Pretoria. (Unpublished MA Dissertation)

SHEAR, T.H. 1995. What is the value of your EAP? EAP Digest, January/February:20-23.

SONNENSTUHL, W.J. \& TRICE, H.M. 1986. Strategies for employee assistance programs: the crucial balance. Cornell University: ILR Press.

STOREY, B. (ed) 2000. Employment practice survey 1(2). Rivonia: Andrew Levy \& Associates.

WILBURN, C. 2007. Helping employees with financial problems. Journal of Employee Assistance, 37(2):12-13.

YAMATINI, H. 1988. EAP benefit and cost structure analysis: a suggested estimation method. Employee Assistance Quarterly, 3(3):129-149.

Ms Cammy Orren, MA student, Prof Lourie Terblanche, Department of Social Work and Criminology, University of Pretoria. 